\section{The Effect of Tillage Treatments on Soil Temperature at Planting and on Corn (Zea mays L.) Yield}

\author{
Miklos Pakurar ${ }^{1}$ - Laszlo Lakatos ${ }^{2}$ - Janos Nagy ${ }^{3}$ \\ University of Debrecen, Centre of Agricultural Sciences, \\ ${ }^{1}$ Institute of Agricultural Economics and Rural Development, \\ Department of Labour Science, Debrecen \\ ${ }^{2}$ Faculty of Agricultural Sciences, \\ Department of Natural Resources, Debrecen \\ ${ }^{3}$ Faculty of Agricultural Sciences, \\ Department of Land Cultivation, Debrecen
}

\section{SUMMARY}

The effect of soil temperature was evaluated on the yield of the Occitan corn hybrid at a depth of $5 \mathrm{~cm}$. We examined this effect on the time required from planting to emergence for three average durations: five, ten and fifteen days, all calculated from the day of planting. Winter plowing $(27 \mathrm{~cm})$, spring plowing $(23 \mathrm{~cm})$, disc-till $(12 \mathrm{~cm})$ treatments and $120 \mathrm{~kg} \mathrm{~N}$ per hectare fertilizer were applied. As a result of our analysis, we determined the post planting optimum soil temperatures for various time periods. The average soil temperature for a time period of 15 days post planting is the most usable for determining actual yields, followed by ten days, with five days proved to be the least usable (winter plow $R^{2}$ $=0.86$, spring plow $R^{2}=0.87$, disc-till $R^{2}=0.64$ ).

\section{INTRODUCTION}

The determination of the exact planting date is one of the most important tasks of corn producers that significantly effect the yield. According to the general opinion of producers, mistakes at planting can not be corrected or such corrections can be costly later. Early planting of corn is recommended because full-season hybrids utilize the entire growing season to achieve increased profit through reduced drying costs.

The date to change from full-season to shorter season hybrids depends on numerous factors, including corn price and drying costs (Lauer et al., 1999). At different stages of development, corn hybrids react differently to meteorological conditions. Varga-Haszonits and Varga (1998) examined the effects of meteorological factors on the length of phenological periods of corn. They stated that the geographical determination of plantingemerging and flowering-maturing period is more important for that of the emergence-flowering period. They pointed out that the planting-emerging period proved the most important due to the yearly changes in the length of the phenological period of the planting-emerging term was the greatest, and the yearly changes in the length of phenological period of emerging-flowering was the least significant.

Berzsenyi et al. (1998) examined the effect of the planting date on the vegetative and generative development of corn. Berzsenyi et al. (1998) studied the dynamics of growth for five different corn hybrids' dependence on the planting date, using growth analysis, in a two year field experiment. In early planting treatments, the length of the plantingemerging period was 14-15 days, in later planting treatments, the length of planting-emerging period decreased to 8-10 days. They found that the length of the planting-emerging period for short-season hybrids was shorter (8-10 days) than for the fullseason hybrids planting emerging period (11-12 days). From the morphological features of corn, the dynamics of height and leaf area vary, depending on the date of planting. The date of planting effected the dynamics of reproductive development of corn hybrids (Berzsenyi et al., 1998).

The speed of yield development value was the greatest in early planting treatments and in optimum planting treatments, however, in late planting treatments, it was reduced. The water content of the corn was significantly higher in late planting treatments than in early planting treatments. The planting date significantly effected the accumulation of dry matter into the corn yield (Berzsenyi et al., 1999). The most accepted method for determining the planting date is the soil temperature at the planting depth. Kovacs et al. (1992) stated that only temperatures under $13{ }^{\circ} \mathrm{C}$ negatively effected the parameters and indexes for corn. The temperature below optimum adversely effected photosynthesis, the pigment synthesis, and hindered the pigments from infiltrating into the membranes during photosynthesis.

According to Helms et al. (1997) the examination of the optimum temperature for germination and the critical water content required are also important, in order to understand the principles of the planting emergence period. The soil temperature and water content of soil change significantly, depending on cultivation methods. Whenever altering between the three cultivation methods, both climate and the meteorological conditions have to be taken into account.

Gyuricza et al. (1999) examined the effects of three cultivation methods on the emergence of corn, using conventional plowing, direct planting and ridge tillage methods. Ridge tillage and direct planting emerged the corn 1-2 days earlier than conventional treatments, due to the favorable microclimate. The cause of earlier emergence was the higher soil temperature brought by ridge treatments and the favorable compactness due to direct planting. The early differences in corn development played no 
significant role at later stages.

Burgess et al. (1996) studied the tillage and crop residue effects on crop production in Quebec. They used no till, reduced till (disc in fall and spring) conventional till (moldboard plow in fall disked in spring) with residue and with no residue. The slowest emergence was experienced in no till treatments with residue.

Swanson and Wilhelm (1996) examined the planting date and residue rate effects on growth, partitioning and of corn yield. The objective of their study was to determine whether the adverse effects of cool soil temperatures on early seedling growths often associated with surface residues, which can be overcome by planting at later dates. Yield declined more rapidly when planting was delayed than when planting was advanced. According to the study, with spring residue application, planting date recommendations can be made independent of residue conditions.

The time and success of emergence depends on the features and treatments of seeds. Berzy et al. (1996) also examined the cold tolerance and vigor of corn seeds. It was found that flat seeds had an advantage over the other shapes. The small round seeds showed the worst result. Berzy et al. (1999) proved that corn seeds treated with fungicide also better tolerated fungous infections and cold.

In this study, we used the data of a multifactorial long-term experiment conducted by Debrecen University Látókép Experimental Farm and Debrecen University Meteorological Observatory. Our aim was to explore the relationship among cultivation methods (winter plow, spring plow, disc till), soil temperature after planting and yield.

\section{MATERIALS AND METHODS}

The multifactoral long-term experiment was designed and managed by Professor Janos Nagy at the Experimental Farm of Department of Crop Sciences and Land Use of Debrecen University. The treatments were tillage, plant density, hybrids, fertilization and irrigation. The experiment consisted of four replications of each combination of treatment.

The analyzed treatments of the long-term multifactorial experiment were:
Hybrid:

Cultivation: A winter plow $(27 \mathrm{~cm})$

B spring plow $(23 \mathrm{~cm})$

C disc-till $(12 \mathrm{~cm})$

Plant density: $\quad 70000 \mathrm{plant} / \mathrm{ha}$

Fertilization: $\quad 120 \mathrm{~kg} \mathrm{~N} / \mathrm{ha}$

The data base derived from the years 1995-1999. The soil was chernozem with lime deposits developed from loess soil. It has moderate supplies of $\mathrm{N}$ and $\mathrm{P}$ and a high $\mathrm{K}$ content. Shortage of microelements could not be detected. The humus content of the soil was $2.72 \%$ in the layer of $0-20 \mathrm{~cm}$. The $\mathrm{pH}$ values were $7.3\left(\mathrm{H}_{2} \mathrm{O}\right)$ and $5.6(\mathrm{KCl})$. The "Arany" type liquid limit was 42 in the upper examined layer. The groundwater level was at about $8 \mathrm{~m}$. The soil was capable of storing $538 \mathrm{~mm}$ of water in the upper $2 \mathrm{~m}$ layer while the soil could store $303 \mathrm{~mm}$ of water in the upper $1 \mathrm{~m}$ layer. The available water content was $307 \mathrm{~mm}$ in the upper $2 \mathrm{~m}$ layer and it was $183 \mathrm{~mm}$ in the upper $1 \mathrm{~m}$ layer.

The data of planting, emergence and tillage treatments of the examined five years are shown in Table 1. Sowing depth was $6 \mathrm{~cm}$.

Table 1: The date of planting and emergence 1995-1999

\begin{tabular}{|c|c|c|c|c|}
\hline Year & $\begin{array}{c}\text { Date of } \\
\text { planting (p) } \\
\text { and }\end{array}$ & \multicolumn{3}{|c|}{ Tillage treatments } \\
\cline { 2 - 5 } & $\begin{array}{c}\text { A } \\
\text { emergence (e) }\end{array}$ & & B & C \\
\hline \multirow{2}{*}{1995} & p. & 05.06. & 05.06. & 05.06. \\
\cline { 2 - 5 } & e. & 05.19. & 05.26. & 05.22. \\
\hline \multirow{2}{*}{1996} & p. & 04.27. & 04.27. & 04.27. \\
\cline { 2 - 5 } & e. & 05.04. & 05.12. & 05.08. \\
\hline \multirow{2}{*}{1997} & p. & 05.02. & 05.02. & 05.02. \\
\cline { 2 - 5 } & e. & 05.16. & 05.22. & 05.20. \\
\hline \multirow{2}{*}{1999} & p. & 04.28. & 04.28. & 04.28. \\
\cline { 2 - 5 } & e. & 05.09. & 05.09. & 05.09. \\
\cline { 2 - 5 } & p. & 05.05. & 05.05. & 05.05. \\
\cline { 2 - 5 } & e. & 05.20. & 05.23. & 05.20. \\
\hline
\end{tabular}

To characterize the precipitation of the examined time period, the sums of yearly precipitation, vegetation periods and their deviation from the 50year average are presented in Table 2.

Table 2: Precipitation 1995-1999

\begin{tabular}{|c|r|r|r|r|}
\hline Year & $\begin{array}{c}\text { Sum of precipitation } \\
\text { yearly }\end{array}$ & $\begin{array}{c}\text { Deviation of the yearly } \\
\text { precipitation from } \\
\text { the 50 year average }\end{array}$ & $\begin{array}{c}\text { Precipitation in the growth } \\
\text { season }\end{array}$ & $\begin{array}{c}\text { Deviation of the growth } \\
\text { season precipitation from } \\
\text { the 50 year average }\end{array}$ \\
\hline 1995 & -88 & 234 & -114 \\
\hline 1996 & 495 & -9 & 400 & 105 \\
\hline 1997 & 574 & -211 & 211 & -84 \\
\hline 1998 & 372 & 57 & 524 & 131 \\
\hline 1999 & 640 & 52 & 388 & 48 \\
\hline
\end{tabular}

The soil temperature values were collected from a depth of $5 \mathrm{~cm}$. Correlation analysis and regression analysis were performed to evaluate the data. The degree of connection between the yield and soil temperature was checked by calculating the significance of deviations. The analysis was completed with graphs. 


\section{RESULTS AND DISCUSSION}

The aim of the statistical analysis was to determine the effect of soil temperature at planting on the quantity of yield. From a statistical point of view, the examined 5-year time period is a short term.

Considering that the variability of the meteorological elements were rather large, dry and wet periods changed, cool and warm periods occurred, the taken samples represent various effects. As the averages of soil temperatures in various periods show, the variations of temperatures are considerable after planting (Figure 1).

Figure 1: Average soil temperature after planting in the depth of $5 \mathrm{~cm}$

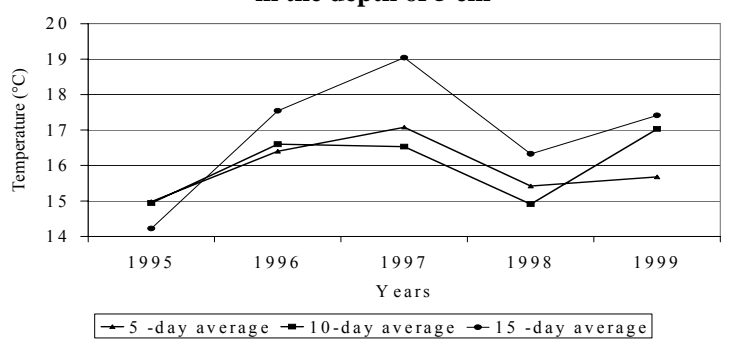

The variability of the meteorological elements make it possible to provide viable statistical analysis, so the drawn conclusions can be generalized.

The effect of soil temperature on the growth of the plants is indisputable. The temperature effects the rate of the physiological processes greatly. The period of germination depends greatly on temperature. Naturally, we also have to take into consideration the water content of the soil. The water content of the soil affects the efficiency and uniformity of emergence. As the graph shows, the water content of the soil fluctuated greatly during the examined years (Figure 2).

Figure 2: Water content of the soil in the upper $50 \mathrm{~cm}$ layer (percentage of water holding capacity)

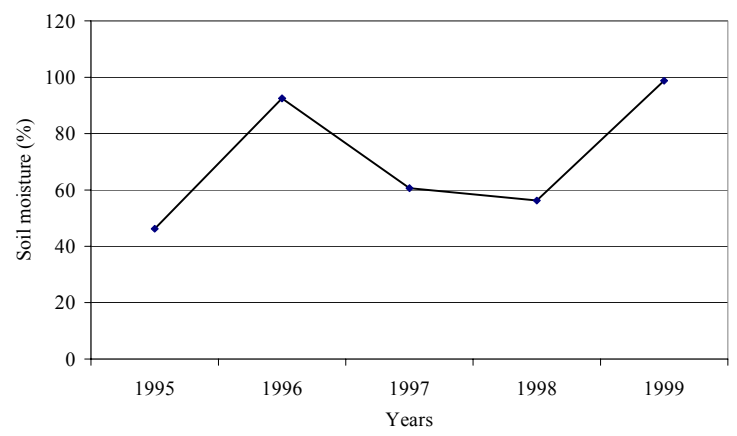

We assume that the driest soil conditions, as measured in 1995, 1997 and 1998, provided enough water for the plants to germinate.

We determined the optimum soil temperature after planting. Quadratic function was fit to soil temperature and yield data, then the maximum of the function was determined by the means of derivation.
The optimum soil temperature of the plantingemergence period was the highest $\left(21-22{ }^{\circ} \mathrm{C}\right)$ at all the three tillage treatments. The optimum soil temperature of the period of 5 days after planting, 10 days after planting and 15 days after planting was 14$19{ }^{\circ} \mathrm{C}$ at all tillage treatments. The soil temperature optimums of the period of 5 days after planting, 10 days after planting and 15 days after planting did not differ significantly in the majority of the cases (Figure 3).

Figure 3: Optimum soil temperature after the planting period, Debrecen 1995-1999

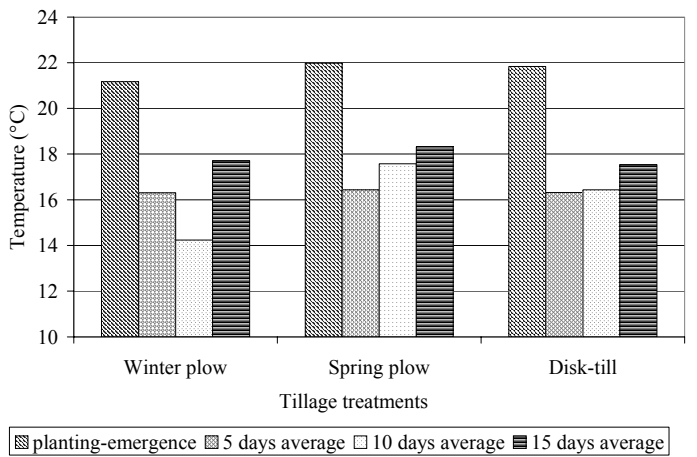

The relationship between the yield and the various examined time periods of soil temperatures can be characterized by quadratic function. This means that the yield has a maximum at a certain value of soil temperature.

The five day period average soil temperature after planting determined the yield most of all in spring plow treatments $\left(\mathrm{r}^{2}=0,62\right)$. The relationship was significant at $\mathrm{P}=5 \%$ (Figure $4 a, b, c)$.

The ten-day-period average soil temperature after planting is also closest connected with the yield in spring plow treatments $\left(\mathrm{r}^{2}=0,27\right)$ (Figure $\left.4 d, e, f\right)$.

The fifteen-day-period average soil temperature after planting and the yield have a significant relationship in all tillage treatments on the level of $\mathrm{P}$ $=5 \%$ or $\mathrm{P}=1 \%$. The closest relationship was also in the spring plow treatments $\left(\mathrm{r}^{2}=0,87, \mathrm{P}=1 \%\right)$ (Figure $5 a, b, c$ ).

The effect of the average soil temperature of planting-emergence period on the yield showed the closest relationship in winter plow and spring plow treatments $\left(\mathrm{r}^{2}=0,54, \mathrm{P}=10 \%\right)$. The average temperature of disk-till treatments did not significantly $\left(\mathrm{r}^{2}=0,21\right)$ affect the yield (Figure $5 d$, $e, f)$.

Analyzing the effect of soil temperature of different time periods after planting on the yield, it can be stated that the soil temperature of a 15-day time period was the best yield determinant. The second best factor that determined yield was the tenday-long average soil temperature. The third best factor that determined yield was the soil temperature of the sowing-emergence time period. The less important yield determinant proved to be the soil temperature of five-day period after planting among the examined time intervals. 
Figure 4: Regression of corn grain yield on the soil temperature, Látókép 1995-1999

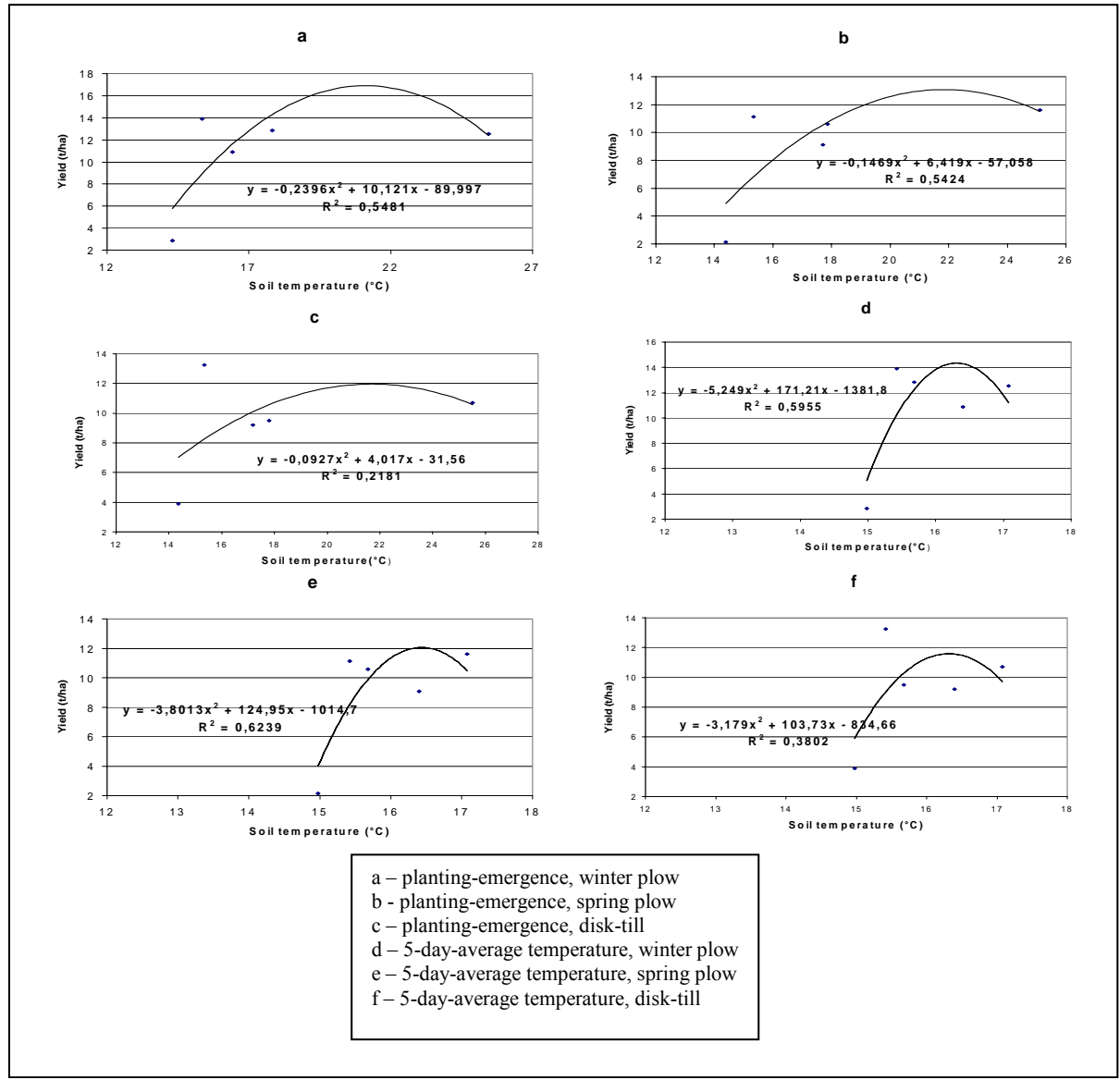

Figure 5: Regression of corn grain yield on the soil temperature, Látókép 1995-1999

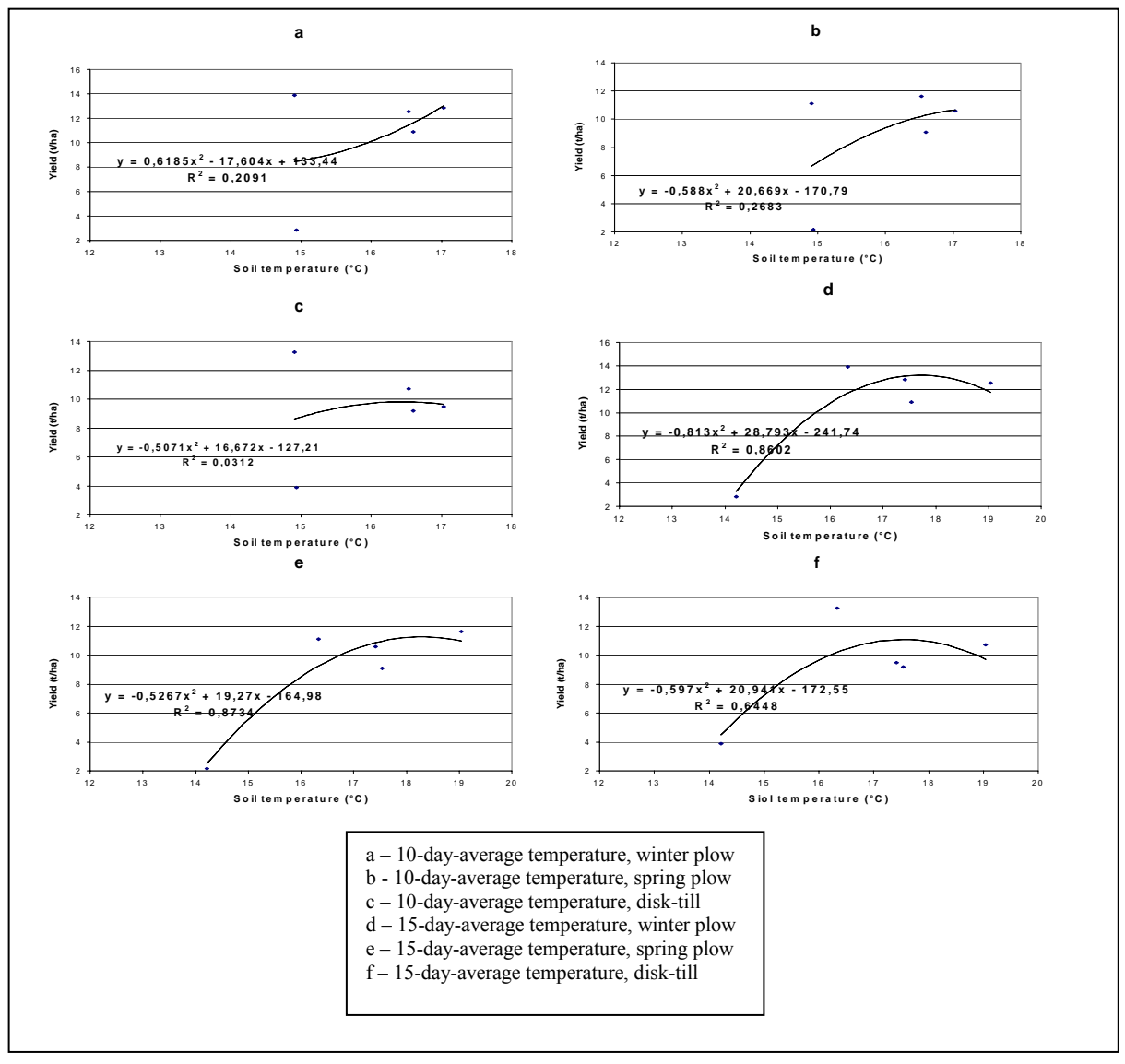




\section{REFERENCES}

Berzsenyi, Z.-Ragab, A. Y.-Lap, D. Q. (1998): A vetésidő hatása a kukoricahibridek reproduktív növekedésének dinamikájára és a szemtermés komponensekre. Növénytermelés, 47. 4. 423438 .

Berzsenyi, Z.-Ragab, A. Y.-Lap, D. Q. (1999): A vetésidő hatásainak vizsgálata kukorica (Zea mays L.) szemtermésének növekedési dinamikájára Richards-függvénnyel. Növénytermelés, 48. 2. 167-188.

Berzy, T.-Marton, Cs.-Feher, Cs. (1996): A frakcionálás hatása a hibridkukorica (Zea mays L.) vetőmag életerejére és szemtermésére. Növénytermelés, 45. 1. 19-26.

Berzy, T.-Zaborszky, S.-Feher, Cs. (1999): A vetőmagkezelések hatása néhány kukorica-genotípus magbiológiai értékére és termésparamétereire. Növénytermelés, 48. 3. 279-288.

Burgess, M. S.-Mehuys, G. R.-Madramootoo, C. A. (1996): Tillage and Crop Residne Effects on Crop Production in Quebec. Agronomy Journal, 88. 792-797.

Gyuricza, Cs.-Liebhard, P.-Laszlo, P.-Birkas, M. (1999): Bakhátas kukoricaművelési rendszer hatása a talaj fizikai állapotára és a termésre. Növénytermelés, 48. 6. 631-646.

Helms, T. C.-Deckard, E. L.-Gregoire, P. A. (1997): Corn, Sunflower, and Soybean Emergence Influenced by Soil Temperature and Soil Water Content. Agronomy Journal, 89. 59-63.

Kovacs, J.-Csapo, B.-Paldi, E.-Szigeti, Z. (1992): Kukorica (Zea mays L.) beltenyésztett törzsek fiatalkori hidegtürésének jellemzése floureszcencia indukciós paraméterek segítségével. Növénytermelés, 41. 2. 97-104.

Lauer, J. G.-Carter, P. R.-Wood, T. M.-Diezel, G. D.-Wiersma, W.-Rand, R. E.-Mlynarek, M. J. (1999): Corn Hybrid Response to Planting Date in Northen Corn Belt. Agronomy Journal, 91. 834-839.

Swanson, S. P.-Wilhelm, W. W. (1996): Planting Date and Residue Rate Effects on Growth, Partitioning, and Yield of Corn. Agronomy Journal, 88. 205-210.

Varga-Haszonits, Z.-Varga, Z. (1998): A meteorológiai tényezők hatása a kukorica fenofázisainak tartamára. Növénytermelés, 47. 5. 503-512. 